\title{
The Prognosis of Adult Burkitt's Cell Leukemia in Real-Life Clinical Practice
}

\author{
Erişkin Burkitt Hücreli Löseminin Klinik Pratikteki Seyri
}

Ümit Yavuz Malkan11, Gürsel Güneş¹, Hakan Göker¹, İbrahim C. Haznedaroğlu11, Kadir Acar², Eylem Eliaçık1, Sezgin Etgül1, Tuncay Aslan1, Seda Balaban1, Haluk Demiroğlu11, Osman I. Özcebe1, Nilgün Sayınalp¹, Salih Aksu1, Yahya Büyükaşık1

${ }^{1}$ Hacettepe University Faculty of Medicine, Department of Hematology, Ankara, Turkey

${ }^{2}$ Gazi University Faculty of Medicine, Department of Hematology, Ankara, Turkey

Abstract

Objective: Many studies reported an improved prognosis in patients with Burkitt's lymphoma obviating the need of stem cell transplantation. However, prognosis of the advanced disease [i.e. Burkitt's cell leukemia $(\mathrm{BCL})]$ has not been reported with current treatment modalities except for a few prospective trials. The aim of this study is to compare the prognoses of BCL patients with similarly treated and nontransplanted patients with other types of acute lymphoblastic leukemia (ALL) and with ALL patients that underwent allogeneic stem cell transplantation (ASCT) in their first remissions.

Materials and Methods: In this retrospective analysis, BCL patients aged between 16 and 63 who were admitted between 2000 and 2014 to the hospitals of Hacettepe or Gazi University and were treated with intensive therapies aimed at cure were included. All ALL patients who were treated with a similar protocol not including transplantation during the same period (NT-ALL group) and all ALL patients who underwent ASCT in the first complete remission during the same period (T-ALL group) served as control groups.

Results: The central nervous system or extramedullary involvement rates, lactate dehydrogenase levels, and white blood cell counts at diagnosis were higher in the BCL group than the NT-ALL group and these differences were significant. BCL patients had disease-free survival (DFS) durations comparable with the T-ALL cohort but NTALL patients had significantly shorter DFS durations. Both cumulative relapse incidence and cumulative nonrelapse mortality were higher in NT-ALL patients compared to the T-ALL group and BCL patients.

Conclusion: DFS in BCL patients treated with a widely accepted modern regimen, R-HyperCVAD, is comparable to results in other ALL patients receiving allogeneic transplantation. Our results are in agreement with a few prospective noncomparative studies suggesting no further need for stem cell transplantation in BCL.

Keywords: Burkitt's cell leukemia, Prognosis

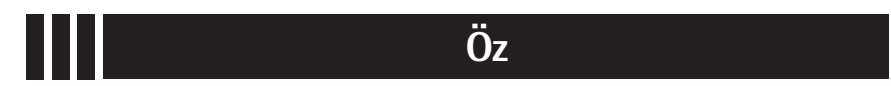

Amaç: Yapılan birçok çalışmada Burkitt lenfomanın seyrinin düzeldiği, hatta kemik iliği nakli ihtiyacının ortadan kalktığı ileri sürülmektedir. Ancak birkaç ileriye dönük çalışma haricinde, güncel tedavi yöntemleri altında hastalığın lösemik formunun seyri hakkında araştırma yapılmamıştır. Bu çalışmanın amacı Burkitt hücreli lösemi (BHL) hastalarının klinik seyrinin, benzer tedavi alan ve transplantasyon uygulanmayan diğer akut lenfoblastik lösemi (ALL) hastaları ve ilk remisyonlarında allojenik kök hücre nakli (AKHN) uygulanan ALL hastalarıyla kıyaslanmasıdır.

Gereç ve Yöntemler: Geriye dönük olarak tasarlanan bu çalışmaya yaşları 16 ile 63 arasında değişen, 2000 ile 2014 yılları arasında Hacettepe ve Gazi Üniversitesi Hastaneleri'ne başvurup kür amacıyla intensif tedavi verilen BHL hastaları alınmıştır. Transplantasyon haricinde benzer tedavi protokolüyle tedavi edilen tüm ALL hastaları (NT-ALL) ve aynı dönemde ilk tam remisyonlarında AKHN uygulanan hastalar (T-ALL) kontrol grupları olarak çalışmaya alınmışlardır.

Bulgular: Santral sinir sistemi ya da ekstra medüller tutulum hızları, tanı anındaki laktat dehidrogenaz düzeyleri ve beyaz küre sayısı BHL hastalarında NT-ALL hastalarına göre istatistiksel olarak anlamlı olacak şekilde daha yüksekti. BHL hastaları T-ALL hastalarıyla benzer hastalıksız sağkalım (HS) süresine sahip olmakla beraber, NTALL hastalarında HS süresi önemli oranda azalmıştı. Kümülatif nüks insidansı ve kümülatif nüks dışı ölümler NT-ALL hastalarında T-ALL ve BHL hastalarında kıyasla daha fazlaydı.

Sonuç: Sonuç olarak, geniş kabul gören modern bir rejim olan R-HyperCVAD ile tedavi edilen BHL hastalarında HS süresi allojenik transplantasyon uygulanmış diğer ALL hastaları ile benzer bulundu. Bizim çalışmamızın sonuçları, literatürde ileri dönük dizayn edilmiş ancak kontrol grupları ile karşılaştırma olmadan yapılmış ve BHL'de transplantasyon gerekmediğini öne süren az sayıdaki çalışma ile örtüşmektedir.

Anahtar Sözcükler: Burkitt hücreli lösemi, Prognoz 


\section{Introduction}

In the last decade, many studies reported an improved prognosis in patients with Burkitt's lymphoma obviating the need for stem cell transplantation. There is a general consensus that the prognosis of Burkitt's lymphoma is closely related to the disease stage and degree regarding the involvement of bone marrow and peripheral blood. However, prognosis of the advanced disease (i.e. Burkitt's cell leukemia) specifically has not been reported with current treatment modalities except for a few prospective trials, which may not reflect everyday real-life clinical practices with their own limitations.

The aim of this study is to compare the prognoses of Burkitt's cell leukemia patients with similarly treated and nontransplanted patients with other types of acute lymphoblastic leukemia and with acute lymphoblastic leukemia patients that underwent allogeneic stem cell transplantation in their first remissions.

\section{Materials and Methods}

\section{Study Population}

In this retrospective analysis, Burkitt's cell leukemia patients aged between 16 and 63 years who were admitted between 2000 and 2014 to the hospitals of Hacettepe or Gazi University and treated with intensive therapies aimed at cure were included in the study. Twenty-five patients who were treated with HyperCVAD \pm rituximab were included in the study; as only one patient was treated with the R-EPOCH regimen, that patient was excluded from the study. The diagnosis of Burkitt's cell leukemia was made based on the presence of characteristic morphological (FAB L3 morphology and $>95 \%$ Ki-67 proliferation index) or cytogenetic/molecular (specific translocations involving MYC at band $8 \mathrm{q} 24$ or MYC rearrangement in fluorescence in situ hybridization analysis) properties and mature B-cell immunophenotype (TdT negativity plus slg positivity of $>20 \%$ or $\kappa / \lambda$ light-chain clonality). The minimal criterion for the diagnosis of a leukemic disease condition was more than $25 \%$ bone marrow involvement. All acute lymphoblastic leukemia patients who were treated with a similar protocol not including transplantation during the same period (NT-ALL group) and all acute lymphoblastic leukemia patients who underwent allogeneic stem cell transplantation in the first complete remission during the same period (T-ALL group) served as control groups.

\section{Treatment Protocols}

Specifics of the HyperCVAD \pm rituximab regimen, including central nervous system (CNS) prophylaxis and treatment strategies, were as described by Thomas et al. [1]. Chemotherapy consisted of 8 alternating courses without maintenance therapy. When given, rituximab was administered during courses 1 to 4 .
Odd courses $(1,3,5,7)$ were HyperCVAD. When given, rituximab was administered at $375 \mathrm{mg} / \mathrm{m}^{2}$ i.v. over 2 to $6 \mathrm{~h}$ on days 1 and 11 of HyperCVAD and on days 2 and 8 of MTX and ara-C, during the first 4 courses.

\section{Study End-Points and Statistical Analysis}

Numerical descriptive data were expressed as median (minimummaximum). Continuous and categorical data were compared with the t-test and chi-square test, respectively. Primary endpoints of the study were complete remission (CR) rate, disease-free survival (DFS), and overall survival (OS). OS was calculated from diagnosis to the date of mortality of any reason. DFS was analyzed in CR patients from date of CR attainment to relapse or death in remission. The patients who did not die and those who did not relapse or die in remission at last follow-up were censored at this time for OS and DFS computations, respectively. Cumulative relapse (CRI) and cumulative nonrelapse mortality incidences (CNRMI) were computed for patients who attained $C R$, from the date of $C R$ until relapse or nonrelapse mortality (NRM), respectively. The patients who did not relapse or die in remission at last follow-up were censored at this time. Relapse was considered a competing risk for NRM, and NRM was considered a competing risk for relapse during CRI and CNRMI computations. Categorical and continuous data were compared by the chi-square and independent-samples t-test, respectively. Survival analyses were computed by the Kaplan-Meier method. Comparisons of survival rates were done by the log-rank test. CRI and CNRMI were calculated according to Gray's test [2] as described by Scrucca et al. [3]. Cumulative incidences were calculated by means of the statistical software environment $\mathrm{R}$, Version 2.15.2 (The R Foundation for Statistical Computing, Vienna, Austria) [4]. SPSS 17.0 (SPSS Inc., Chicago, IL, USA) was used for other statistical analyses.

\section{Results}

T-ALL patients were frequently referred after remission attainment from other centers. Some of these patients' baseline parameters were missing. There were 25, 44, and 48 patients in the Burkitt's cell leukemia, NT-ALL, and T-ALL groups, respectively. Important baseline characteristics of Burkitt's cell leukemia and NT-ALL patients are presented in Table 1. All 25 Burkitt's cell leukemia patients had been treated with the HyperCVAD \pm rituximab regimen and were not transplanted. Rituximab treatments were given to most of the Burkitt's cell leukemia patients; only 3 Burkitt's cell leukemia patients had not received rituximab. Only nontransplanted acute lymphoblastic leukemia (NT-ALL) patients who were treated with HyperCVAD were selected as controls. Median numbers of HyperCVAD \pm rituximab regimens given to Burkitt's and NT-ALL patients were 8 and 7.5, respectively. The CNS or extramedullary involvement rate, lactate dehydrogenase levels, and white blood cell count at diagnosis were higher in 
the Burkitt's group than the NT-ALL group and these differences were significant ( $p=0.008, p=0.016$, and $p=0.036$, respectively). We also analyzed the chemotherapy intervals between treatment cycles. There was no significant difference between the intervals of treatment cycles for the Burkitt's cell leukemia and NT-ALL groups. The median (95\% confidence interval) OS time for all 25 Burkitt's cell leukemia patients was 31.1 (3.159.1) months. The mean (95\% confidence interval) DFS time for Burkitt's cell leukemia patients was 50.0 (30.9-69.2) months (median not reached). After analyzing the prognosis, we further analyzed the induction chemotherapy results and OS in the patients with Burkitt's cell leukemia receiving HyperCVAD and similarly treated nontransplanted acute lymphoblastic leukemia patients. Transplanted acute lymphoblastic leukemia patients were preferentially not included in this analysis because the majority of them had been referred after remission attainment from other centers. After the induction therapy, 5 patients died, 19 patients achieved $C R$, and 1 patient had no response in the Burkitt's cell leukemia group. Four patients died, 33 patients achieved CR, and 7 patients had no response in the NT-ALL group. We achieved a 76\% CR rate in the Burkitt's group and a $75 \%$ CR rate in the NT-ALL group ( $p=0.182$ ). The median (95\% confidence interval) OS time for the Burkitt's and NT-ALL groups were 31.1 (3.1-59.1) and 12.1 (7.0-17.3) months, respectively $(p=0.261)$. There was no significant difference between the two groups (Figure 1). After obtaining these results, we analyzed the DFS, CRI, and CNRMI in the 3 groups. The mean DFS time for the Burkitt's, NT-ALL, and T-ALL groups was 50.0 $\pm 9.7,31.4 \pm 6.7$, and $83.3 \pm 9.1$ months, respectively ( $p=0.002)$. There was a significant statistical difference between these 3 groups (Figure 2). Burkitt's cell leukemia patients had DFS durations comparable with the T-ALL cohort $(50.0 \pm 9.7$ vs. $83.3 \pm 9.1$ months, respectively; $\mathrm{p}=0.17$ ), but NT-ALL patients had significantly inferior DFS durations compared to the T-ALL group ( $31.4 \pm 6.7$ vs. $83.3 \pm 9.1$ months, respectively; $p=0.001)$. Both CRI (45.4\% [standard error, SE: $9.8 \%], 38.2 \%$ [SE: 7.8\%], and 35.7\% [SE: 12.5\%] at the $80^{\text {th }}$ month; $\mathrm{p}=0.04$ ) and CNRMI (28.5\% [SE: 8.8\%], 6.8\% [SE: 3.9\%],

Survival Functions

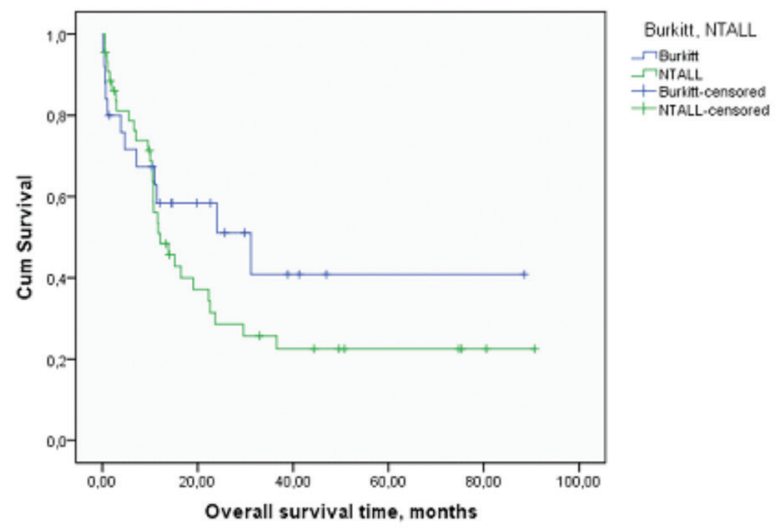

Figure 1. Overall survival time for Burkitt and NTxALL groups. and $11.5 \%$ [SE: $8 \%$ ] at the $80^{\text {th }}$ month; $p=0.03$ ) were higher in NT-ALL patients compared to the T-ALL group and Burkitt's cell leukemia patients (Figure 3).

\section{Discussion}

As stem cell transplantation for Burkitt's cell leukemia has been abandoned in the modern era, we preferred to evaluate success of current treatment in these cases by comparing them with similarly treated NT-ALL and T-ALL patients. Currently, allogeneic stem cell transplantation is deemed necessary in adult acute lymphoblastic leukemia during the first complete remission. We thought that in the absence of possibilities of evaluating the value of allogeneic stem cell transplantation in Burkitt's cell leukemia by a randomized study or by using a currently transplanted Burkitt's cohort, the necessity of treatment could be weighed by comparison of Burkitt's cell leukemia cases with T-ALL and NT-ALL patients. Transplanted acute lymphoblastic leukemia patients had the best DFS, significantly better than that of nontransplanted patients. However, no DFS advantage could be observed in transplanted patients compared to Burkitt's cell leukemia patients.

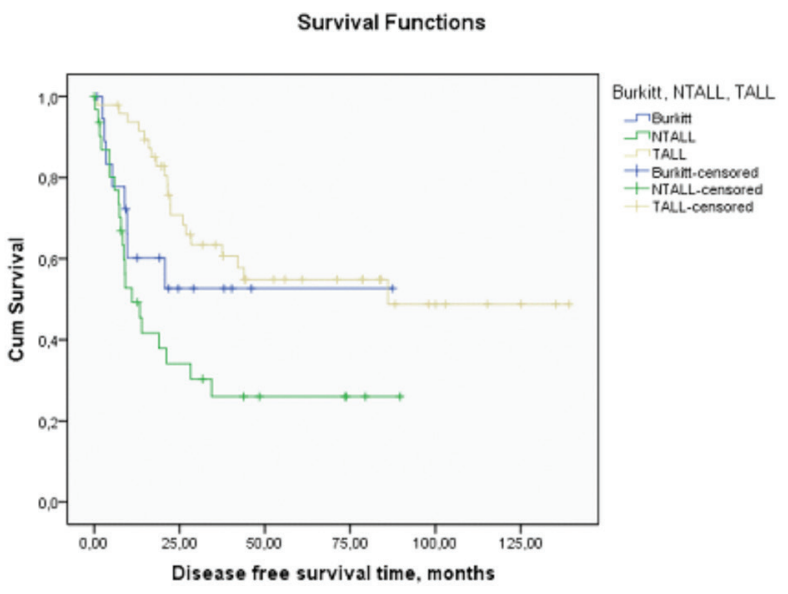

Figure 2. Disease-free survival time of Burkitt, NTxALL, and TxALL groups.

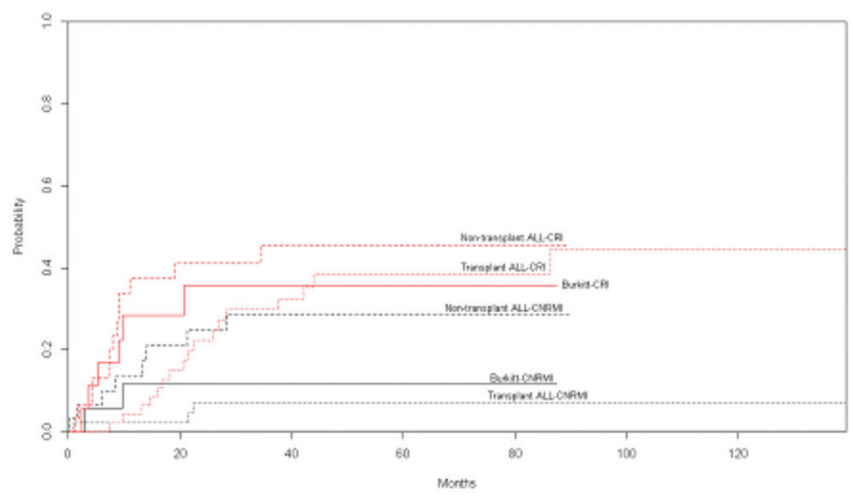

Figure 3. Cumulative relapse and cumulative nonrelapse mortality incidences of Burkitt, NTXALL, and TxALL groups. 


\begin{tabular}{|c|c|c|c|}
\hline Parameters & Burkitt's Cell Leukemia Group & Non-Transplant ALL Group & p-value \\
\hline Sex (Male/Female) & $18 / 7$ & $23 / 21$ & 0.086 \\
\hline ECOG performance score $(0 / 1 / 2 / 3 / 4)$ & $3 / 16 / 3 / 3 / 0$ & $12 / 21 / 4 / 5 / 2$ & 0.438 \\
\hline Hemoglobin at diagnosis (g/dL) & $10.0(4.9-14.0)$ & $9.1(4.0-15.5)$ & 0.920 \\
\hline Leucocyte count at diagnosis (x109/L) & $9.6(1.7-24.7)$ & $8.8(0.8-216.4)$ & 0.036 \\
\hline Platelet count at diagnosis (x109/L) & $103.5(11-631)$ & $53.5(8-560)$ & 0.141 \\
\hline Chemotherapy Interval 1-2nd, days & $26.5(18-33)$ & $28.0(17.0-45.0)$ & 0.521 \\
\hline Chemotherapy Interval 5-6 $6^{\text {th }}$, days & $30.0(24.0-46.0)$ & $29.0(22.0-43.0)$ & 0.395 \\
\hline Chemotherapy Interval 6-7th, days & $37.5(27.0-42.0)$ & $29.0(23.0-40.0)$ & 0.087 \\
\hline Chemotherapy Interval 7-8 ${ }^{\text {th }}$, days & $31.0(24.0-45.0)$ & $29.0(22.0-40.0)$ & 0.148 \\
\hline Central Nervous System or Extramedullary involvement (Y/N) & $12 / 14$ & $7 / 37$ & 0.008 \\
\hline Blasts in peripheral blood film $(\mathrm{Y} / \mathrm{N})$ & $8 / 4$ & $15 / 12$ & 0.515 \\
\hline Blasts in marrow <25\%, 25\%-50\%, >50\% & $1 / 0 / 11$ & $0 / 1 / 24$ & 0.275 \\
\hline Follow-up time for surviving patients, months & $22.7(1.4-88.5)$ & $38.6(0.5-90.7)$ & \\
\hline \multicolumn{4}{|c|}{ LDH: Lactate dehydrogenase, ECOG: The Eastern Cooperative Oncology Group, Y/N: Yes/No } \\
\hline
\end{tabular}

In our study, we achieved a $76 \%$ CR rate after induction therapy in Burkitt's cell leukemia cases. In a study conducted by a German group, an 86\% CR rate was achieved in Burkitt's cell leukemia patients [5]. In another study conducted in Italy, investigators obtained a $79 \% \mathrm{CR}, 8 \%$ no-response rate, and $13 \%$ death rate in Burkitt's lymphoma and leukemia patients after induction chemotherapy [6]. In our study, we obtained 76\% CR, 20\% death, and 4\% no-response rates in Burkitt's cell leukemia patients. The induction death rate in our study was higher than that of the Italian study. The reason for this difference may be that participants were in an advanced stage of disease (Burkitt's cell leukemia) in our study, whereas patients in the Italian study had both Burkitt's lymphoma and leukemia. Furthermore, in the Italian study, investigators found a relapse rate of only $7 \%$ in patients treated with an intercycle interval of $\leq 25$ days. We found the CRI of Burkitt's cell leukemia patients as $35.7 \%$, which was much higher. The intercycle interval could be the reason for this difference, because in our study the mean duration of all chemotherapy intercycles was longer than 25 days. It is known that men are more commonly affected by Burkitt's disease with a 3-4:1 ratio [7]. Similarly, in our cohort, men were more common, with a ratio of 2.5:1.

In reported clinical trials, the prognosis for Burkitt's lymphoma is generally favorable, with median survivals of $75 \%-90 \%$ with modern chemoimmunotherapy regimens $[1,8]$. An analysis of the Surveillance Epidemiology and End Results (SEER) database was less encouraging, however, with a 5-year OS rate of 56\% and better survival seen in younger patients with lowerrisk disease (87\% and $71 \%$ for patients aged 0-19 years and for patients with low-risk disease, respectively) $[9,10]$. The impact of age on outcomes is likely multifactorial and reflects increased treatment toxicity or decreased treatment intensity in older individuals, as well as the potential misclassification of disease in this population. In our study the mean OS time for all 25 Burkitt's cell leukemia patients was $43.6 \pm 9.2$ months. Burkitt's lymphoma principally involves the lymph nodes, bone marrow, and CNS, but it may also present with peripheral blood involvement [11]. In our study, peripheral blood involvement was present in 66\% of cases. A limitation of our study is that in the T-ALL group DFS duration after first CR was found comparable but OS duration was not calculable.

In conclusion, DFS in Burkitt's cell leukemia patients treated with a widely accepted modern regimen, R-HyperCVAD, is comparable to that of allogeneic transplanted patients of acute lymphoblastic leukemia. Although this study has some disadvantages inherent to its retrospective design, use of nonBurkitt's control groups, and a limited patient numbers, we think that a better comparative study design is practically impossible due to the absence of a large transplanted Burkitt's cohort and ethical issues in planning a prospective study including transplantation in these patients. Our results are in agreement with the few prospective noncomparative studies $[12,13]$, 
suggesting no further need for stem cell transplantation in Burkitt's cell leukemia.

\section{Ethics}

Informed Consent was taken during the hospital admission of the patients, additional Ethics Committee Approval was not applicable based on the nature of this retrospective analysis.

\section{Authorship Contributions}

Medical Practices: Ümit Yavuz Malkan, Gürsel Güneş, Hakan Göker, İbrahim C. Haznedaroğlu, Kadir Acar, Eylem Eliaçık, Sezgin Etgül, Tuncay Aslan, Seda Balaban, Haluk Demiroğlu, Osman i. Özcebe, Nilgün Sayınalp, Salih Aksu, Yahya Büyükaşık; Concept: Ümit Yavuz Malkan, Yahya Büyükaşı; Design: Ümit Yavuz Malkan, Yahya Büyükaşı;; Data Collection or Processing: Ümit Yavuz Malkan, Gürsel Güneş, Hakan Göker, İbrahim C. Haznedaroğlu, Kadir Acar, Eylem Eliaçık, Sezgin Etgül, Tuncay Aslan, Seda Balaban, Haluk Demiroğlu, Osman İ. Özcebe, Nilgün Sayınalp, Salih Aksu, Yahya Büyükaşık; Analysis or Interpretation: Ümit Yavuz Malkan, Yahya Büyükaşı; Literature Search: Ümit Yavuz Malkan; Writing: Ümit Yavuz Malkan.

Conflict of Interest: The authors of this paper have no conflicts of interest, including specific financial interests, relationships, and/or affiliations relevant to the subject matter or materials included.

\section{References}

1. Thomas DA, Faderl S, O'Brien S, Bueso-Ramos C, Cortes J, Garcia-Manero G, Giles FJ, Verstovsek S, Wierda WG, Pierce SA, Shan J, Brandt M, Hagemeister $F B$, Keating MJ, Cabanillas F, Kantarjian H. Chemoimmunotherapy with hyper-CVAD plus rituximab for the treatment of adult Burkitt's and Burkitt's-type lymphoma or acute lymphoblastic leukemia. Cancer 2006;106:1569-1580.

2. Gray RJ. A class of K-sample tests for comparing the cumulative incidence of a competing risk. Ann Stat 1988;16:1141-1154.

3. Scrucca L, Santucci A, Aversa F. Competing risk analysis using R: an easy guide for clinicians. Bone Marrow Transplant 2007;40:381-387.
4. Team RDC. R: A Language and Environment for Statistical Computing. Vienna, Austria, R Foundation for Statistical Computing, 2012.

5. Hoelzer D, Walewski J, Döhner $H$, Schmid M, Hiddemann W, Baumann A, Serve $H$, Dührsen U, Hüttmann $A$, Thiel $E$, Dengler J, Kneba $M$, Schuler $M$, Schmidt-Wolf I, Beck J, Hertenstein B, Reichle A, Domanska-Czyz K, Fietkau $R$, Horst HA, Rieder H, Schwartz S, Burmeister T, Goekbuget N. Substantially improved outcome of adult Burkitt's non-Hodgkin lymphoma and leukemia patients with rituximab and a short-intensive chemotherapy; report of a large prospective multicenter trial. Blood 2012;120:667a (abstract).

6. Intermesoli T, Rambaldi A, Rossi G, Delaini F, Romani C, Pogliani EM, Pagani C, Angelucci E, Terruzzi E, Levis A, Cassibba V, Mattei D, Gianfaldoni G, Scattolin AM, Di Bona E, Oldani E, Parolini M, Gökbuget N, Bassan R. High cure rates in Burkitt's lymphoma and leukemia: a Northern Italy Leukemia Group study of the German short intensive rituximab-chemotherapy program. Haematologica 2013;98:1718-1725.

7. Morton LM, Wang SS, Devesa SS, Hartge $P$, Weisenburger DD, Linet MS Lymphoma incidence patterns by WHO subtype in the United States, 19922001. Blood 2006;107:265-276.

8. Magrath I, Adde M, Shad A, Venzon D, Seibel N, Gootenberg J, Neely J, Arndt C, Nieder M, Jaffe E, Wittes RA, Horak ID. Adults and children with small non-cleaved-cell lymphoma have a similar excellent outcome when treated with the same chemotherapy regimen. J Clin Oncol 1996;14:925-934.

9. Castillo JJ, Winer ES, Olszewski AJ. Population-based prognostic factors for survival in patients with Burkitt's lymphoma: an analysis from the Surveillance, Epidemiology, and End Results database. Cancer 2013;119:3672-3679.

10. Costa $\sqcup$, Xavier AC, Wahlquist AE, Hill EG. Trends in survival of patients with Burkitt's lymphoma/leukemia in the USA: an analysis of 3691 cases. Blood 2013;121:4861-4866.

11. Swerdlow SH, Campo E, Harris NL, Jaffe ES, Pileri SA, Stein H, Thiele J, Vardiman JW. WHO Classification of Tumours of Haematopoietic and Lymphoid Tissues. Lyon, France, IARC Press, 2008.

12. Maramattom LV, Hari PN, Burns U, Carreras J, Arcese W, Cairo MS, Costa U, Fenske TS, Lill M, Freytes CO, Gale RP, Gross TG, Hale GA, Hamadani M, Holmberg LA, Hsu JW, Inwards DJ, Lazarus HM, Marks DI, Maloney DG, Maziarz RT, Montoto S, Rizzieri DA, Wirk B, Gajewski JL. Autologous and allogeneic transplantation for Burkitt lymphoma outcomes and changes in utilization: a report from the Center for International Blood and Marrow Transplant Research. Biol Blood Marrow Transplant 2013;19:173-179.

13. Maruyama D, Watanabe T, Maeshima AM, Nomoto J, Taniguchi H, Azuma T, Mori M, Munakata W, Kim SW, Kobayashi Y, Matsuno Y, Tobinai K. Modified cyclophosphamide, vincristine, doxorubicin, and methotrexate (CODOX-M)/ ifosfamide, etoposide, and cytarabine (IVAC) therapy with or without rituximab in Japanese adult patients with Burkitt lymphoma (BL) and B cell lymphoma, unclassifiable, with features intermediate between diffuse large B cell lymphoma and BL. Int J Hematol 2010;92:732-743. 